\title{
Floods in the north-western Mediterranean region: presentation of the HYMEX database and comparison with pre-existing global databases
}

\author{
M. Carmen LlASAT ${ }^{1}$, Montserrat LlASAT-BOTIJA, Olga PETRUCCI², Angela Aurora PASQUA², \\ Joan ROSSELLO ${ }^{3}$, Freddy VINET ${ }^{4}$, Laurent BOISSIER ${ }^{4}$
}

\author{
1. GAMA (Meteorological Hazards Analysis Team) Department of Astronomy and Meteorology Faculty of Physics, University of Barcelona, Spain \\ carmell@am.ub.es,mllasat@am.ub.es \\ 2. CNR-IRPI (Istituto di Ricerca per la Protezione Idrogeologica), Cosenza, Italy o.petrucci@irpi.cnr.it, pasqua@irpi.cnr.it \\ 3. Grup de Climatologia, Hidrologia, Riscs Naturals i Territori. Universitat Illes Balears, Palma de Mallorca, Spain, joan.rossellogeli@uib.es \\ 4.Laboratoire GRED. Université Montpellier 3/IRD, France freddy.vinet@univ-montp3.fr, laurent.boissier@univ-montp3.fr
}

\begin{abstract}
The contribution presents the database on floods (1981-2010) that is being developed in the framework of HYMEX project and the preliminary results obtained for the NW sector of Mediterranean region. This database contains data on damages and the main hydrometeorological features of each reported event. The study is included in one of the objectives of the Working Group 5, which is a transversal group of the HYMEX project dealing with all the aspects related to societal and ecological impacts of hydrometeorological extremes, as well as their perception and communication processes. One of the main points of the WG5 is the creation of a common database on floods and their societal impact, for the Mediterranean region, as well as its analysis. Although some databases already exist and are frequently consulted, they are mainly focused on "major" catastrophic events. But the Mediterranean region experiences every year a high number of minor flash-floods that, considered in their totality, produce important losses and disruptions of the everyday life. This contribution is focused on North-Eastern Spain, South of Italy and South-East of France and the objective is to include all the floods that have produced damages, although they are not considered as "major" disasters.
\end{abstract}

Key-words: floods, flash-floods, societal impact, damages, Mediterranean Region.

\section{Les inondations dans le nord-ouest de la Méditerranée : comparaison avec les bases de données globales}

\begin{abstract}
RÉSUMÉ. - La contribution présente la base de données sur les inondations développée dans le cadre du projet HYMEX et les résultats préliminaires obtenus pour la partie nord-ouest de la région méditerranéenne. Cette base de données, couvrant la période 1981-2010, contient des données sur les dommages et sur les principales caractéristiques hydrométéorologiques de chaque événement inventorié. L'étude constitue l'un des objectifs du groupe de travail 5, groupe transversal du projet HYMEX qui traite des impacts sociétaux et écologiques des phénomènes hydrométéorologiques extrêmes, de leur perception et de la communication. L'un des principaux chantiers du groupe de travail 5 est la création et l'analyse d'une base de données commune sur les inondations et leurs impacts sociétaux dans les pays méditerranéens. Bien que certaines bases de données existent déjà et soient fréquemment consultées, elles visent principalement les événements majeurs. Mais la Méditerranée connait chaque année un nombre élevé de crues éclairs mineures qui, considérées dans leur ensemble, produisent d'importantes pertes et perturbent les activités socio-économiques. Cette contribution est axée sur le nord-est de l'Espagne, le sud de l'Italie et le sud-est de la France. L'objectif est d'inclure toutes les inondations qui ont produit des dommages, même si elles ne sont pas considérées comme des catastrophes.
\end{abstract}

Mots-clés : inondations, crues éclairs, impact social, dommages, Région Méditerranée.

\section{INTRODUCTION}

The interest of the scientific community for the analysis of societal impacts of hydro-meteorological processes is increasing year by year, as is demonstrated by the great number of contributions on this topic in international scientific journals. However, this kind of analysis is not easy to perform. It requires an interdisciplinary vision, not only by the authors but also by the journal, editors and reviews. The involved disciplines usually depend on the point of view from which the societal impact is addressed. In the hydrometeorological community, the most usual is to focus on natural hazards and climate change. In this case, the analysis of social impact ranges from the vulnerability of structures [Elmer, et al., 2010] to the analysis of social perception and communication [Llasat, et al., 2009], including economic impact and cost-benefit studies [Barredo, 2009; Noy, 2009], warning systems and the role of different agents involved in the emergency [Llasat, Siccardi, 2010], insurances and resilience [Amaro, et al., 2010], ecological impacts [AusAID, 2005], population density and urban development [Llasat, et al., 2008], and factors involved in losses of life [Jonkman, Vrijling, 2008]. A second problem deals with the vocabulary. The concept associated to words like risk, vulnerability, 
hazard or exposure, for instance, can change completely when they are used by the meteorological community or by other scientific communities [Hollenstein, 2005]. The differences in the definitions of these words by the IPCC [2007] or the UNISDR [2009] illustrate this state of facts. The third problem, and not the least one, is the difficulty to acquire the necessary data for this kind of approaches. Obviously it depends on the research objective, but usually data come from insurance companies, newspapers, specific post-event inquiries, or technical reports, that in most of the cases have to be complemented by hydrometeorological data. Problems due to scarcity, heterogeneity and inaccuracy of published data can be the source of intrinsic mistakes [Petrucci, 2012; Petrucci, Pasqua, 2008; 2009], and it is not unusual to find contradictory data on damages, date of the events, and so on.

In this context, the objective of this contribution is to present the database on floods that is being developed within the HYMEX project and the preliminary results obtained for the North-Western Mediterranean region. The HYMEX project (Hydrological Mediterranean Experiment) is focussed on the analysis of all the components involved in the water cycle in the Mediterranean area, with emphases on the predictability and evolution of intense events by monitoring and modelling the Mediterranean coupled system (atmosphere-land-ocean), its variability (from the event scale, to the seasonal and inter-annual scales) and characteristics over one decade (2010-2020) in the context of global change [Bouwer, 2011]. The project is structured in five working groups (WG). The objective of WG5 is to evaluate the societal and economical vulnerability to extreme events and climate change and the adaptation capacity. It includes heavy rainfalls, droughts and water scarcity, and the impact of climatic change on these risks and water resources. One of the main points of the WG5 is the creation of a common database on floods and their societal impacts for the Mediterranean region, as well as its analysis.

This paper illustrates the problems encountered while building this database and the first results of analysis. After a presentation of the most relevant existing databases, the different criteria and data sources are presented. A comparison with the EM-DAT and NATHAN databases is done. In this paper, the term "floods" covers flood and flash-flood events.

\section{FLOOD DATABASE}

Although some international databases already exist and are frequently consulted, they are mainly focused on major catastrophic events. This is the case of the Emergency Events Database (EM-DAT) from the Centre for Research on the Epidemiology of Disasters of the Université Catholique de Louvain, and the Natural Hazards Assessment Network (NATHAN) of the reinsurance firm Munich Re. A third database is the European Severe Weather database, from the European Severe Storm Laboratory, that also includes other severe weather phenomena, like tornadoes, hailstorms etc. For floods, one of the reference databases is the Darmouth flood observatory archive. http://www.dartmouth.edu / floods/ Currentt.htm).

The database presented in this paper merges the following local databases:

- The FLASH floods database [Llasat et al., 2010a]: it refers to the entire Mediterranean region. It has been built in the European project FLASH [Price, et al., 2011] and it has included all the floods inventoried in the EM-DAT, NATHAN (1981-2003) and ESWD databases, as well as information from the European projects SPHERE and HYDRATE, the Interreg actions RINAMED, HYDROPTIMET and AMPHORE, and the WMO/WCRP project MEDEX, and the past UNESCO AMHY/FRIEND project. It includes 185 flood events for the period 1990-2004. The main problem lies in the heterogeneity of the information. This database is the core of the HYMEX database.

- The INUNGAMA floods database [Barnolas, Llasat, 2007]: it refers to Catalonia (Northeast of Spain) and contains 212 flood events for the $20^{\text {th }}$ century. Recently it has been updated and comprises the period 1900-2007, with a total of 356 flood events [Llasat, et al., 2010b]. This database also includes the floods of the three main rivers in Catalonia occurred since the $14^{\text {th }}$ century (Llobregat River, Segre River, Ter River). This database has been updated until 2010 in the context of this contribution. Every flood event for which information is available has been included. Main sources of information have been newspapers, technical reports, scientific papers and, for some cases, hydrometeorological data. Finally, 213 flood events have been recorded for the period 1981-2010.

- The University of Balearic Islands floods database: it contains 36 flash flood events recorded in the Balearic Islands (Spain) for the period 1981-2010 and more than 100 flood events since the $15^{\text {th }}$ century. For this database the criterion used for the selection has been the existence of information on a flood event. The dates of the event and the affected basins were located using sources like regional newspapers, local weekly papers, and regional and local administration reports and, for the period 1981-1991 a main source was the thesis of Miquel Grimalt (1992). Onsite surveys were also conducted, mainly for the period 1990-2010.

- The PRIM-NET database [MEDDTL, 2011]: it refers to all natural disaster in France and only includes catastrophic flood events (damages over 3 million $€$ and casualties), with a total number of 70 floods events over the period 1910-2010. 29 flood events included in this database for the period 1981-2010 and that have affected the South East of France (Languedoc-Roussillon, Midi Pyrenees, PACA) were extracted from this database.

- The ASICal floods and landslides database, collecting events occurred since the XIX Century [Petrucci and Pasqua, 2008; 2009]: it is focused on the Calabria region (South Italy) and, for the study period 1981-2010, it includes 155 flood, heavy precipitation and landslide events, from which, 107 are floods. Data came from different sources: newspapers articles, national and regional agencies (civil protection, public works offices, etc.) and, for more recent cases, even from onsite surveys (interviews with people involved or local administrators). Only events that have affected 5 municipalities or more have been included in this database.

Merging this information a common flood database for the selected regions (Catalonia, Balearic Islands, South East of France -Midi Pyrenees, Languedoc-Roussillon, PACA- and Calabria) has been built. The objectives of this database are:

- To define a methodology that could be applied to other regions in order to have a homogeneous and complete Mediterranean flood database (the HYMEX-Societal Impact database, HYMEX-SI).

- To identify common events.

- To analyse specific events. 
- To analyse flood series (climatological analysis, economic information, data about circumstances of losses of life, trends,...).

- To reveal the importance of minor but frequent events.

The selected period for the flood inventory has been 19812010 , with the idea of covering a climatic period of 30 years.

The main problems encountered when the common database has been built where:

- To find hydrometeorological data, mainly estimated river discharges.

- To select sufficiently representative rainfall data (in space and time) to assess the hydrometeorological severity of the events (maximum cumulated precipitation and rainfall rate, extension of the event,..).

- To obtain accurate information about damages (public and privates) and casualties. In some countries data from insurances are not public.

- Newspapers were a major source of information but a part of the scientific community considers this kind of information source as moderately reliable and often not comprehensive.

- The accuracy of damage data included in a database may vary greatly depending on the data sources and should be rated in the database according to the level of detail of the sources.

- To find information to locate damage data, because floods affect areas that can be delimited only by means of on-site surveys (which cannot be performed for all past events).

- To find an objective criterion to isolate individual events during prolonged rainy periods.

- To set a table of damageable elements and indicators, simple and usable in different geographical contexts.

- Some minor flood events are not reported by the press and go unnoticed; on the contrary "great" databases only contain catastrophic events and can induce an overestimation of the effects of these events.

\section{FIRST PRELIMINAR RESULTS}

Figure 1 shows a comparison between the number of flood events identified in this preliminary HYMEX database and the EM-DAT and the NATHAN databases for the period 1981-2010 (in the case of NATHAN, not public information after 2003 is available). The great differences are mainly due to the criteria applied for the inclusion of disasters in the database. A disaster is registered in EM-DAT when at least

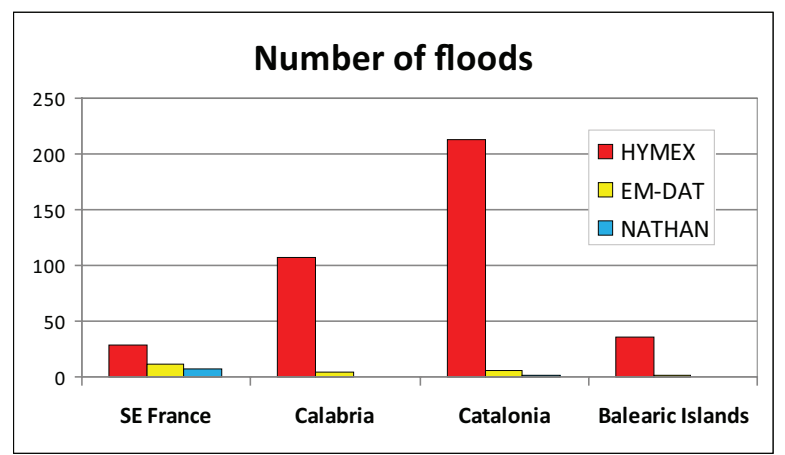

Figure 1: Comparison between the number of floods identified for the four selected regions in the HYMEX, EM-DAT and NATHAN databases for the period 1981-2010 (NATHAN: 1981-2003). one of the following criteria is fulfilled: a) 10 or more people killed; b) 100 or more people affected/injured/homeless; c) it is a significant disaster; d) it induced significant damages; e) declaration of a state of emergency and/or an appeal for international assistance [Barredo, 2009]. NATHAN database includes the events considered as "great natural disaster". It is the case when there are thousands of fatalities, when hundreds of thousands of people are made homeless, or when the economic losses reach exceptional orders of magnitude [Barredo, 2009]. These criteria are similar to those followed by the French PRIM-NET database, that requires more than 3 million $€$ or at least one fatality.

However, in the region analysed here, flash floods with minor damages and disruption of regular life are produced every year, and the cumulative effect of all of them implies high damages and has imposed regulatory rules for urbanization and preventive measures. Then in the present HYMEX flood database, the objective would be to include as many floods and flash floods as possible without any threshold. However, as this information is not available for all the regions analysed here, a classification criterion has been applied. This criterion is the same used to classify historical floods, and distinguish between ordinary, extraordinary and catastrophic events (for more information see Llasat et al, 2005, 2008). All the floods included in the EM-DAT, NATHAN and PRIMNET databases belong to the catastrophic case.

The case of Catalonia illustrates the impact of non-catastrophic events: only $10 \%$ of the flood events can be considered as catastrophic ones, $53 \%$ can be classified as extraordinary flood events, while $36 \%$ are only ordinary floods. For this region there is only one flood event included in the NATHAN database, and only 6 in the EM-DAT database, when 213 flood events producing damages have been identified. For Calabria and Balearic Islands no flood is reported in NATHAN, and only 4 and 1 are included in EM-DAT, when 107 and 36 events have been identified respectively. Moreover, in France where at least 29 catastrophic floods occurred, the NATHAN and EMDAT databases only include 7 and 12 events respectively. Although Figure 2 only includes flood events classified as catastrophic, the message is the same: the global databases tend to considerably underestimate the number of flood events produced in the NorthWestern part of the Mediterranean Region. Therefore, both the temporal distribution of floods and the damages can be completely different when global or local detailed databases are analysed. One example is the strong frequency of flashfloods in summer in the analysed regions, when it is typical

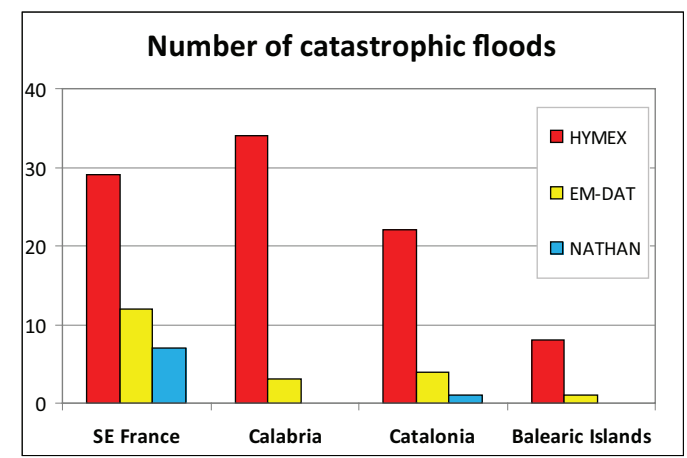

Figure 2: Comparison between the number of catastrophic floods identified for the four selected regions in this study and the EM-DAT and NATHAN databases for the period 1981-2010 (NATHAN: 1981-2003). 
Table 1: Comparison between the number of flood events identified in the preliminary HYMEX database and the EM-DAT and the NATHAN databases, for the period 1981-2010 (exception, NATHAN database only considers 1981-2003).

\begin{tabular}{|l|c|c|c|c|c|c|}
\hline & \multicolumn{2}{|c|}{ Number of flood events (events with deaths) } & \multicolumn{2}{c|}{ Number of catastrophic flood events } \\
\hline & HYMEX & EM-DAT & NATHAN & HYMEX & EM-DAT & NATHAN \\
\hline PACA-LR-MP (SE France) & $29(18)$ & $12(9)$ & $7(6)$ & $29(18)$ & $12(9)$ & $7(6)$ \\
\hline Calabria & $107(7)$ & $4(3)$ & $0(0)$ & $34(5)$ & $3(2)$ & $0(0)$ \\
\hline Catalonia & $213(42)$ & $6(5)$ & $1(1)$ & $22(15)$ & $4(4)$ & $1(1)$ \\
\hline Balearic Islands & $36(5)$ & $1(1)$ & $0(0)$ & $8(4)$ & $1(1)$ & $0(0)$ \\
\hline
\end{tabular}

to consider that they do not usually occur in this season. For instance, on the $1^{\text {st }}$ of August 2002, $248 \mathrm{~mm} / 24 \mathrm{~h}$ where recorded on the Catalan coast, some streams overflowed inducing one casualty and important damages.

Table 1 includes the same type of comparison but with the number of events that have produced casualties. From a total number of 385 flood events recorded in the study area, 19\% have induced casualties out of which only $58 \%$ belong to the category of catastrophic floods. When it is compared with the other databases, the proportion between events producing casualties and total number of flood events increases up to $78 \%$ an $87.5 \%$, for the EM-DAT and NATHAN databases respectively. In spite of these ratios, both global databases underestimate the number of casualties, like in the Catalan region, where they have recorded 5 and 1 events with casualties, respectively, when 42 events induced casualties. Over the period 1980-2003, this great difference is the same: 284 events (64 catastrophic ones) are recorded in the HYMEX database, 16 have been identified by EM-DAT and 8 by NATHAN.

\section{CONCLUSIONS}

A comprehensive database including moderate as well as major floods in Mediterranean countries is an indispensable requirement to assess the real social impact of floods in Mediterranean countries. However, due to the heterogeneity of information sources (mainly, newspapers, administrative and historical reports and insurances companies) and periods (since $14^{\text {th }}$ century until only the last decades), it is not an easy task to build such comprehensive databases. Global databases do not include the numerous moderate floods that represent a source of great economic and human damages as illustrated herein. To find common criteria that allow establishing a unified database to compare flood events (not only major ones) and consequences is fundamental. As an example, the recent catastrophic flood event recorded in Genoa on November 2011 has also produced extraordinary floods in Catalonia, Balearic Islands and in Var department in Southern France.

The better solution would be to create complete regional databases in each country and share the information on floods and criteria. This is the case in France, where a specific work has been undertaken under the Flood Directive, with a collation of about 2000 flooding events over the country (Lang et al, 2013). But, unfortunately, the lack of funds and national sponsorship in other countries do not facilitate to follow this example. For this reason, and following personal initiatives, a common database that covers the last 30 years is being built in the framework of the HYMEX programme, starting from some specific regions. At the moment, 385 flood events have been identified for the period 1981-2010, in Catalonia and Balearic islands (Spain), Calabria (Italy) and South-Eastern France. The main objectives will be to improve the knowledge on fatalities due to floods and the circumstance; the economic impacts and their evolution; the societal perception and the analysis of trends. In the future, the databases will also have to answer the need of an accurate and standardized monitoring of damages (human and material) and the possibility to test the connection between the hazard data (rainfall threshold, discharges) and the consequences of floods. Eventually, the HYMEX database might be a great help to assess the efficiency of the mitigation measures and the possibility to improve them. Besides this, one regional database like this provides more accurate and consistent information than global databases and can be very useful for regional analyses.

\section{ACKNOWLEDGEMENTS}

This paper has been developed in the framework of the HYMEX project and with the support of the European project DRIHM.

\section{REFERENCES}

Amaro J., Gayà M., Aran M. \& Llasat M.C. (2010) Preliminary results of the Social Impact Research group of MEDEX: the request database (2000-2002) of two meteorological services. Nat. Haz. Earth Syst. Sci. 10 : 2643-2652

Ausaid (Australian Agency For International Development) (2005) - Economic impact of natural disasters on development in the Pacific 2: Economic Assessment Tools. [http:// www.ausaid.gov.au/publications/pdf/impact_pacific_tools.pdf]

Barnolas M., Llasat M.C. (2007) — A flood geodatabase and its climatological applications: the case of Catalonia for the last Century. Nat. Haz. Earth Syst. Sci. 7 : 271-281

BARREDo J. I. (2009) — Normalised flood losses in Europe: 19702006. Nat. Haz. Earth Syst. Sci. 9 : 97-104

BouwER L.M. (2011) - Have disaster losses increased due to anthropogenic climate change? Bull. Amer. Meteor. Soc. 92 : 39-46

Elmer F., Thieken A.H., Pech I. \& Kreibich. H. (2010) Influence of flood frequency on residential building losses. Nat. Haz. Earth Syst. Sci. 10 : 2145-2159

Grimalt M. (1992) - La geografia del risc a Mallorca. Les inundacions. Institut d'Estudis Balearics. Palma de Mallorca.

Hollenstein K. (2005) - Reconsidering the risk assessment concept: Standardizing the impact description as a building block for vulnerability assessment. Nat. Haz. Earth Syst. Sci. $5: 301-307$

IPCC (2007) — Climate Change 2007. The Physical Science Basics. Summary for Policymakers. 
Jonkman S. N., VRiJling J. K. (2008) — Loss of life due to floods. Journal of Flood Risk Management. 1 : 43-56

Lang M., Ceeur D., Bard A., Bace B., Becker T., Bignon E., Blanchard R., Bruckmann L., Delserieys M., Edelblutte C. (2013) - Les inondations remarquables en France au XX $\mathrm{X}^{\mathrm{e}}$ siècle : premiers éléments d'analyse issus de l'enquête EPRI. La Houille blanche à paraître

Llasat M.C., Barriendos M. \& Rigo T. (2002) - L'analyse de la fréquence et de l'occurrence temporelle des fortes précipitations d'origine méditerranéenne causes des crues rares en Espagne et dans le sud de la France. La Houille Blanche. 6-7 : 139-144

Llasat M.C., M. Barriendos, Barrera A., And Rigo T. (2005) - Floods in Catalonia (NE Spain) since the 14th century. Climatological and meteorological aspects from historical documentary sources and old instrumental records. Journal of Hydrology. Applications of palaeoflood hydrology and historical data in flood risk analysis. 313 : 32-47

Llasat M.C., Llasat-Botija M. \& López L. (2009) A press database on natural risks and its application in the study of floods in northeastern Spain [www.nat-hazards-earth-syst-sci. net/9/2049/2009/]. Nat. Haz. Earth Syst. Sci. 9 : 2049-2061

Llasat M.C., Llasat-Botija M., Prat M.A., Porcú F., Price C., Mugnai A., Lagouvardos K., Kotroni V., Katsanos D., Michaelides S., Yair S., Savvidou K. \& Nicolaides K. (2010) - High-impact floods and flash floods in Mediterranean countries: the flash preliminary database. Advances in Geosciences. 23 : 1-9

Llasat M.C., Llasat-Botija M., Rodríguez A. \& Lindbergh S. (2010) - Flash floods in Catalonia: a recurrent situation. Advances in Geosciences. 26 : 105-111

Llasat M. C., López L., Barnolas M. \& Llasat-BotiJa M. (2008) - Flash-floods in Catalonia: the social perception in a context of changing vulnerability. Advances in Geosciences. 17 : 63-70
Llasat M.C., Siccardi F. (2010) - A reflection about the social and technological aspects in flood risk management - the case of the Italian Civil Protection. Nat. Hazards Earth Syst. Sci. 10 : 109-119

Meddtl (French Ministry Of Environment) (2011) - Tableau des événements naturels dommageables survenus en France de 1900 à $2010 \quad$ [http://catalogue.prim.net/94_tableau-desevenements-naturels-dommageables-survenus-en-france-de1900-a-2010.html]

Noy I. (2009) - The macroeconomic consequences of disasters Journal of Development Economics. 88 : 221-231

Petrucci. O. (2012) - Assessment of the impact caused by natural disasters: simplified procedures and open problems. Managing Disasters - assessing hazards, emergencies and disaster impacts, J.P. Tiefenbacher Ed, INTECH, Open Access Publisher. ISBN 979-953-307-006-2. 109-132

Petrucci O., Pasqua A.A. (2008) - The study of past Damaging Hydrogeological Events for damage susceptibility zonation. Nat. Haz. Earth Syst. Sci. 8 : 881-892

Petrucci O., Pasqua A.A. (2009) - A methodological approach to characterise Landslide Periods based on historical series of rainfall and landslide damage. Nat. Haz. Earth Syst. Sci. 9 : $1655-1670$

Price C., Yair Y., Mugnai A., Lagouvardos K., Llasat M.C., Michaelides S., Dayan U., Dietrich S., Di Paola F., Galanti F., Garrote L., Harats N., Katsanos D., Kohn M., Kotroni V., Llasat-Botija M., Lynn B., Mediero L., Morin E., Nicolaides K., Rozalis S., Savvidou K. \& Ziv B. (2011) Using Lightning Data to Better Understand and Predict Flash Floods in the Mediterranean. Surv. Geophys. 32 : 733-751

UNISDR (2009) - UNISDR Terminology on Disaster Risk Reduction [http://www.unisdr.org/eng/terminology/terminology-2009-eng. html] 